\title{
LONG-TERM MORPHOMETRIC VARIATIONS IN A POPULATION OF THE DEEP-SEA SHRIMP ARISTEUS ANTENNATUS (RISSO, 1816) (DECAPODA, ARISTEIDAE)
}

\author{
BY \\ C. BAS and F. SARDÀ \\ Institut de Ciències del Mar (CSIC), Plaça del Mar s/n, E-08039 Barcelona, Spain
}

\begin{abstract}
The objective of this study was to analyze possible morphometric variations in the relationship among various measurements of the body parts of Aristeus antennatus, in the course of a long period of time (30 years). The same appendages were measured in the same way and with the same precision in 1965 and 1995. To avoid differences caused by sexual dimorphism only females were analyzed. The relative growth of the tail appendages of Aristeus antennatus (telson and external uropod) increased. The scaphocerite and the abdomen length remained practically without change. The length of the articles of the third and fourth pereiopods did not differ, but the total length of the pereiopods was significantly reduced. The existence of possible morphometric changes in the swimming structures in relation to environmental changes is discussed, especially in relation to the decrease of food resource, and to benthic disturbance, caused by increasing fishing pressure.
\end{abstract}

\section{RESUMEN}

El objetivo del presente estudio es comprobar si existen diferencias morfométricas entre distintas medidas del cuerpo de Aristeus antennatus, entre dos períodos de tiempo separados 30 años (datos procedentes de 1965 y 1995). Las medidas de los apéndices fueron tomados, en ejemplares hembras, de la misma manera y con la misma precisión en los dos períodos de tiempo. Se observó que el desarrollo de los apéndices caudales, urópodo externo y telson, tienen crecimiento alométrico, aumentando su tamaño relativo con el tiempo. El escafocerito y el abdomen permanencen inalterados, de la misma forma que los artejos de los pereiópodos tercero y cuarto. Estos últimos presentan una ligera tendencia a dismunuir su longitud, aunque de manera no significativa; sin embargo, la longitud total de los pereiopodos presenta una disminución significativa. Se discuten estos cambios de los apéndices natatorios en relación a los cambios ambientales, concretamente en función de la disminución del recurso alimentario y del incremento de la perturbación sobre el sustrato causado por el aumento del esfuerzo pesquero. 


\section{INTRODUCTION}

Aristeus antennatus (Risso, 1816), is a deep-sea species from depths ranging from 400 to more than $2000 \mathrm{~m}$ in the study area, the Catalan Sea. It is traditionally exploited in the Mediterranean area and the adjacent Atlantic coasts (Bas et al., 1955; Tobar \& Sardà, 1987; Demestre \& Martín, 1993).

At the Catalan coast (western Mediterranean), research on the biology and the fishery of this species was initiated during the 1950's (Arté, 1952) and the 1960's (Bas, 1960, 1966; Bas et al., 1955). Later, a series of studies was undertaken about its biology (Sardà \& Demestre, 1989; Demestre \& Fortuño, 1992; Demestre, 1995; Sardà \& Cartes, 1997), ecology (Sardà \& Cartes, 1993; Sardà et al., 1994), and fisheries (Tobar \& Sardà, 1992; Demestre \& Lleonart, 1993; Demestre \& Martín, 1993).

Recently, Sardà et al. (1995) studied the functional morphology of Aristeus antennatus in relation to size and sex, and pointed out the importance of some appendages (uropods, scaphocerite, and pereiopods) to mobility and equilibrium during swimming. Sardà et al. (in press), studying several populations from the Atlantic and the Mediterranean, observed genetic, but not morphometric uniformity in all the populations. They concluded that there exists a morphometric plasticity in this species, which makes it possible to adapt the length of certain appendages to different environmental conditions.

Comparing the relative growth of different body measurements in fishes, Bas (1964) suggested that marine species in more stable environments (e.g., deepsea habitats) tend to isometric growth. The higher environmental stability of the deep-sea would make them to adapt to a functional equilibrium of their appendages. Sardà et al. (in press), observed that shrimp populations in the western Mediterranean, from 400 to $700 \mathrm{~m}$ depth, have significantly longer uropods than populations in the Atlantic and the eastern Mediterranean. However, shrimp populations dwelling beyond $1000 \mathrm{~m}$ depth have intermediate morphometric characteristics, similar to all other populations.

The objective of this study was to look for morphometric variation in the relationships among different measurements of the body parts of Aristeus antennatus, over a long period of time; data were collected in 1965 and in 1995. Since there is no information available in the literature regarding such long-term changes, we advance the hypothesis of environment-mediated morphometric changes in the shrimp population in the Catalan Sea (and possibly in the whole Mediterranean), related to the decrease of food resources and the increase in benthic disturbance, linked to increased fishing pressure. 


\section{MATERIAL AND METHODS}

In order to verify temporary variations in morphometric relationships of various body parts in Aristeus antennatus, samples were taken from the port of Blanes in 1965 and 1995 (fig. 1). To avoid differences caused by sexual dimorphism only females were analyzed. The same appendages, in the same way and with the same precision were measured (fig. 2). This was made possible by the conservation of the 1965 data, and because all measurements were carried out by the same author $(\mathrm{C}$. Bas). All the linear magnitudes were taken by calipers rounded to the nearest 0.05 or $0.10 \mathrm{~mm}$. It is considered that the precision and error margin in the measurements taken is minimal, because the distances correspond to hard structures, ending up in single straight edges or in a spine. The lengths were measured of: the carapace, total body, scaphocerite, telson, external uropod, and merus, carpus and propodus of the third and fourth pereiopods. These last three lengths were summed as total length of the third and fourth pereiopod. A more accurate description of these measurements can be found in Sardà et al. (1995).

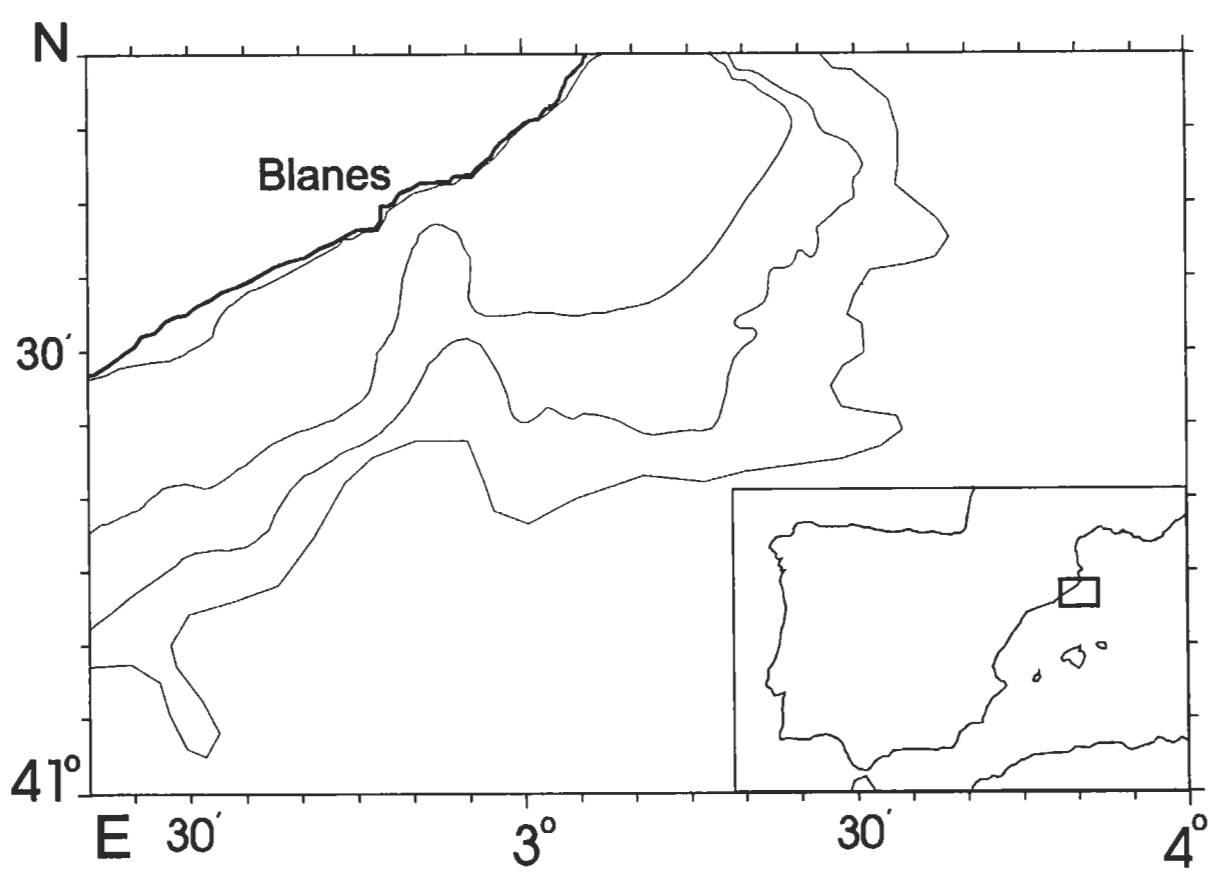

Fig. 1. Fishing grounds of Aristeus antennatus (Risso, 1816), in the study area. 


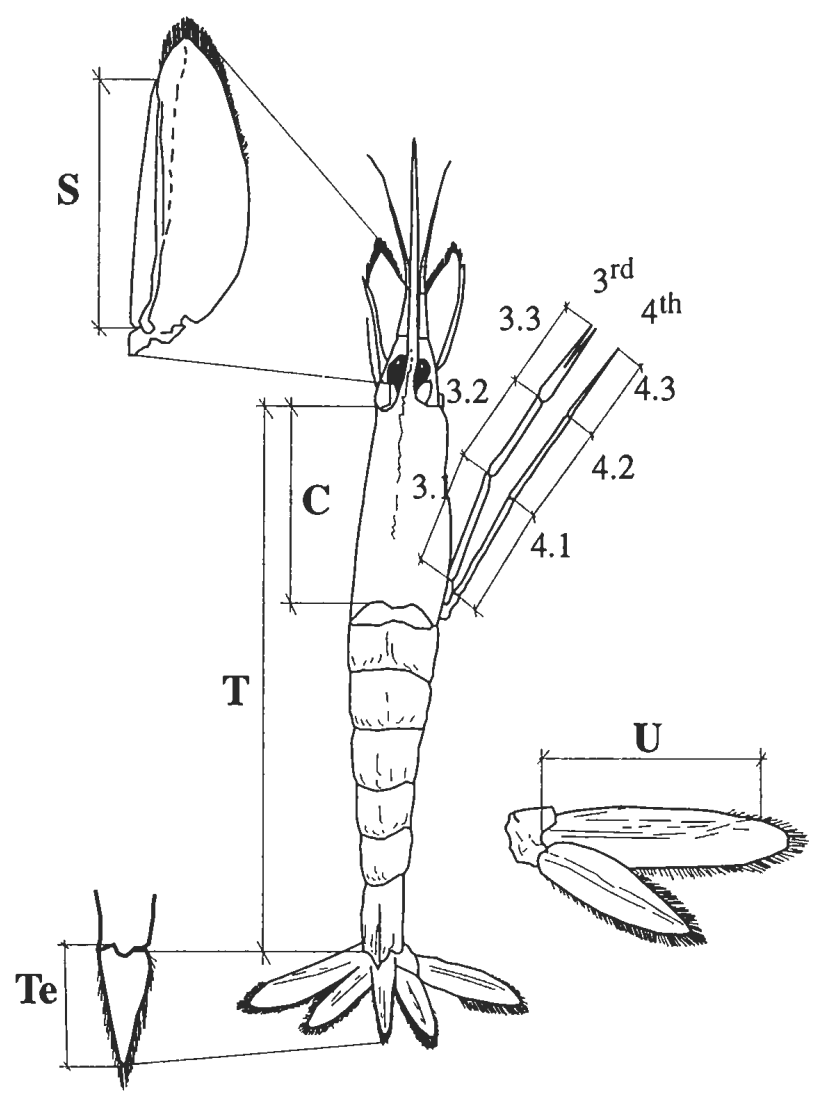

Fig. 2. Morphometric measurements taken on Aristeus antennatus (Risso, 1816): C, carapace; $\mathrm{T}$, total length; S, scaphocerite; Te, telson; U, external uropod; 3rd, third pereiopod (3.1, merus;

3.2 , carpus; 3.3 , propodus); 4 th, fourth pereiopod (4.1, merus; 4.2 , carpus; 4.3 , propodus).

After logarithmic transformation of the data, the slopes of the regression lines between several appendages and cephalotorax length (CL), taken as an independent variable, were obtained as:

$$
\ln y=\ln a+b \ln x+\varepsilon
$$

This method was discussed and justified in Sardà et al. (1995). The comparison between slopes was carried out by means of ANOVA $(P<0.05)$. Two tests among the samples of each period were made: (1) slope comparisons between different morphometric relationships $\left(\mathrm{H}_{0}: \mathrm{b}_{65}=\mathrm{b}_{95}\right)$, to identify possible differences in time, and (2) test of allometry $\left(\mathrm{H}_{0}: b=1\right)$, to observe the type of allometry and the changes that could have taken place. The significance of all 
the regressions was tested by ANOVA, being significant for $P<0.05$ (Sokal \& Rohlf, 1979).

\section{RESULTS}

Most magnitudes present allometry (table $\mathrm{I}$, columns $\mathrm{b}_{65}=1$ and $\mathrm{b}_{95}=1$ ). The external uropod, telson, and fourth pereiopod present negative allometry. Nevertheless, these appendages present significant differences between 1965 and 1995 , indicating their increased growth between the two periods. The total length and the scaphocerite length remained unchanged (column $b_{65}=b_{95}$ ). Articles of the third and fourth pereiopods did not decrease in relative length, but total pereiopod length decreased when lengths of individual articles were totalled.

On the other hand, the number of pereiopod articles where $b$ is different from 1 also varies between 1965 and 1995. Five of the six articles of the pereipods as well as the totals of the measurements had slopes significantly different from 1 in 1995. The articles of the third and fourth pereiopods tended to decrease their relative length, although these variations were not significant (column $b_{65}=b_{95}$ ). Only the total lengths differ significantly. The individual comparison of the slopes indicates that a tendency exists towards the reduction of the total pereiopod length. The lower regression coefficients corresponding to the propodus of the fourth pereiopod are explained by the shape and consistence of the article. This propodus is extremely fine (hair-like) and, in many cases, can have a broken tip, which is difficult to detect at first sight.

In the course of the 30 years, the swimming appendages of Aristeus antennatus grew relatively larger, increasing the relative length of the telson and the external uropod. The scaphocerite length remained unchanged and the articles of the pereiopods tended to a reduction in length.

\section{DISCUSSION}

A variation in the morphometric relationships of the telson and the external uropod length of Aristeus antennatus, is shown by comparing morphometric data for 1965 and 1995. The scaphocerite length remained unchanged. Sardà et al. (1995) identified the scaphocerite as the appendage providing equilibrium during the back impulse, the characteristic swimming pattern of shrimps. The abdomen constitutes the muscular mass responsible for the impulse. The uropods (in this case, only the external uropod) and the telson, act as an oar, enlarging the pushing surface. The results presented here suggest that the population has increased its swimming ability during the period 1965-1995. 
TABLE I

Values of relative growth parameters and level of statistical significance for each measured variable. $N$, number of individuals measured; $a, y$-intercept; $b$, slope; $R$, correlation coefficient; $b=1$, allometric significance; $\mathrm{b}_{65}=\mathrm{b}_{95}$, significant differences of the slope values between 1965 and 1995; * $P<0.05$; ${ }^{* * *}, P<0.0001$; ns, not significant; =, without difference; obs., observations; inc.: increase; dec., decrease

\begin{tabular}{|c|c|c|c|c|c|c|c|c|c|c|c|c|}
\hline \multicolumn{6}{|c|}{1965} & \multicolumn{7}{|c|}{1995} \\
\hline Measure/CL & $N$ & $a$ & $b$ & $R$ & $b=1$ & $N$ & $a$ & $b$ & $R$ & $b=1$ & $b_{65}=b_{95}$ & obs. \\
\hline Total & 896 & 1.987 & 0.772 & 0.969 & $* * *$ & 318 & -2.492 & 0.759 & 0.985 & $* * *$ & ns & $=$ \\
\hline Uropod & 144 & 1.125 & 0.568 & 0.905 & $* * *$ & 318 & 0.732 & 0.684 & 0.954 & $* * *$ & $* * *$ & inc. \\
\hline Scaphocerite & 245 & 0.325 & 0.775 & 0.961 & $* * *$ & 318 & 0.454 & 0.772 & 0.976 & $* * *$ & ns & $=$ \\
\hline Telson & 417 & 0.921 & 0.628 & 0.860 & $* * *$ & 318 & -0.078 & 0.817 & 0.970 & $* * *$ & $* * *$ & inc. \\
\hline Merus 3.1 & 160 & -0.831 & 1.020 & 0.916 & ns & 318 & -0.509 & 0.933 & 0.973 & $* * *$ & ns & $=$ \\
\hline Carpus 3.2 & 160 & -1.211 & 1.156 & 0.921 & $* * *$ & 318 & -1.056 & 1.117 & 0.976 & $* * *$ & ns & $=$ \\
\hline Propodus 3.3 & 160 & -1.009 & 1.067 & 0.918 & ns & 318 & -0.893 & 1.037 & 0.955 & ns & ns & $=$ \\
\hline Total 3rd leg & 160 & 0.709 & 1.084 & 0.921 & $*$ & 318 & 1.614 & 0.645 & 0.821 & $* * *$ & $* * *$ & dec. \\
\hline Merus 4.1 & 143 & -0.396 & 0.940 & 0.841 & ns & 318 & -0.318 & 0.936 & 0.967 & $* * *$ & ns & $=$ \\
\hline Carpus 4.2 & 143 & -0.375 & 0.925 & 0.917 & ns & 318 & -0.155 & 0.880 & 0.965 & $* * *$ & ns & $=$ \\
\hline Propodus 4.3 & 143 & 0.693 & 0.589 & 0.759 & $* * *$ & 318 & 0.665 & 0.508 & 0.782 & $* * *$ & ns & $=$ \\
\hline Total 4th leg & 143 & 1.179 & 0.784 & 0.850 & $* * *$ & 318 & 1.963 & 0.552 & 0.811 & $* * *$ & $* * *$ & dec. \\
\hline
\end{tabular}


The last two pereiopods did not show differences with time and they do not participate in the swimming movements. Their development is more or less related to sustaining the shrimp on the sea floor during foraging and cropping activity. The third pereiopod presents a dactyl (chela), used to "crop" within the substrate, while the fourth pereiopod ends in a very fine, non-chelate dactyl. Its function would be rather sensorial. In contrast to what happens to the swimming appendages, the slopes of the data for the pereiopods decreased.

Our results are evidence of increased mobility, during the last 30 years. We suggest that this is linked to persisting environmental stress, inducing morphometric, non-genetic changes. Aristeus antennatus is a target commercial species in the study area, trawled by a relatively monospecific fleet. The species forms dense schools of 50 to 100 individuals for $10,000 \mathrm{~m}^{2}$ over middle slope grounds (Sardà, unpubl. data). The adults lack specific and important competitors (Relini \& Wurtz, 1977).

Fishing pressure has increased dramatically in the last 30 years in the study area. It is estimated that an average effort of near $800 \mathrm{HP}$ was employed in 1965 (Sardà \& Tobar, 1987), while it was more than 8000 HP in 1995 (table II). The increase in power represents an increase in the size of the trawlers as well as the gear size, and improvements in accompanying technology (GPS positioning, weather prediction, remote control of gear over the bottom, manoeuvre speed, etc.).

As a consequence, the fishing grounds are continuously disturbed and the epifaunal food resources for shrimps decrease progressively. An increase in swimming ability could be an answer to this disturbance, in order to increase activity, either to escape being captured by means of the natatory backward impulse (as is the typical means of fast escape reaction in decapods (Main \& Sangster, 1984)) or to enhance food search on more mobile organisms. Cartes \& Sardà (1989) and Cartes (1994) observed a relatively high proportion of mobile epibenthic (peracarid crustaceans) and benthopelagic invertebrates (euphausiids or decapods; such as Sergestes arcticus Krøyer, 1855 or Pasiphaea sp.) in the

\section{TABLE II}

Development of the fishing effort on the Catalan coast during 20 years. Data rewritten from Martín (1991) and Franquesa (1996)

\begin{tabular}{lccr}
\hline Year & No. of boats & GRT & HP \\
\hline 1973 & 487 & 12,787 & 64,390 \\
1983 & 458 & 18,633 & 122,789 \\
1993 & 407 & 18,863 & 123,795 \\
\hline
\end{tabular}

Legends: GRT $=$ Gross Registered Tonnage; HP $=$ Horse Power. 
habitual diet of Aristeus antennatus, reaching near $20 \%$ of the stomach content. Sardà et al. (in press) detected shorter uropods in species from Israel, attributing this phenomenon to the more stable hydrological conditions in the eastern Mediterranean Sea. These authors also indicate that current western Mediterranean Aristeus antennatus populations (from Spain (Alboran and Catalan Seas), France (Gulf of Lions), and the Balearic Islands) do not present morphological differences, when comparing similar magnitudes. This would indicate that there can be differences in the course of time, but not among current populations in the same geographical zone.

In summary, we propose the hypothesis that the long-term morphometric variations observed in Aristeus antennatus serve a more active food search when foraging on mobile resources and a general increase in mobility, in order to compensate for the increased sea-floor disturbance due to increased fishing activity.

\section{ACKNOWLEDGEMENTS}

The present study was funded by the Institut d'Estudis Catalans (Barcelona). The authors wish to express their appreciation to Dr. F. Maynou for his critical revision of the manuscript and Dr. I. Palomera for her help during the computing process. Thanks also to Ms. G. Fuster and Mr. J. M. Anguita for their technical assistance.

\section{LITERATURE CITED}

ARTÉ, P., 1952. Datos biológicos sobre Aristeus antennatus Risso del "Sot de la Gamba" de Blanes (Crustacea, Macrura, Natantia). Publ. del Inst. de Biol. apl., 10: 145-149.

BAS, C., 1960. Variaciones de la pesca de crustáceos de fondo. IV. Reunion sobre Prod. y Pesca del Instituto de Investigaciones Pesqueras: 91-93.

_ —, 1964. Aspectos del crecimiento relativo en peces del Mediterráneo occidental. Investigación Pesquera, Barcelona, 27: 13-119.

— - 1966. La gamba rosada (Aristeus antennatus). Publ. Téc. J. de Est. de Pesca, 5: 143-155.

BAS, C., E. Morales \& M. Rubió, 1955. Cataluña. La pesca en España, 1: 1-468. (Instituto de Investigaciones Pesqueras, Barcelona).

CARTES, J. E., 1993. Day-night feedings by decapod crustaceans in a deep-water bottom community in the western Mediterranean. Journ. mar. biol. Association, U.K., 73: 795-811.

- - 1994. Influence of depth and season on the diet of the deep-water aristeid Aristeus antennatus along the continental slope (400 to $2300 \mathrm{~m}$ ) in the Catalan Sea (western Mediterranean). Mar. Biol., 120: 639-648.

_ - 1995. Diets of, and trophic resources exploited by, bathyal penaeoidean shrimps from the western Mediterranean. Mar. Freshwater Res., 46: 889-896.

CARTES, J. E. \& F. SARDÀ, 1989. Feeding ecology of the deep-water aristeid crustacean Aristeus antennatus. Mar. Ecol. Progr. Ser., 54: 229-238. 
DEMESTRE, M., 1995. Moult activity-related spawning success in the Mediterranean deep-shrimp Aristeus antennatus (Decapoda: Dendrobranchiata). Mar. Ecol. Progr. Ser., 127: 57-64.

DEmestre, M. \& J. M. ForTuÑo, 1992. Reproduction of the deep-water shrimp Aristeus antennatus (Decapoda: Dendrobranchiata). Mar. Ecol. Progr. Ser., 84: 41-51.

Demestre, M. \& J. LleonART, 1993. Population dynamics of Aristeus antennatus (Decapoda: Dendrobranchiata) in the northwestern Mediterranean. Sci. Mar., 57 (2-3): 183-189.

Demestre, M. \& P. MARTín, 1993. Optimum exploitation of a demersal resource in the western Mediterranean: the fishery of the deep-water shrimp Aristeus antennatus (Risso, 1816). Sci. mar., 57 (2-3): 175-182.

FRANQUESA, R., 1996. Quantitative analysis of the relations which condition the north western Mediterranean fishing system. CEC. contract $n^{\circ}$ DGXIV-MED/93/022: 150.

MaIN, J. \& G. I. SANGSTER, 1984. The behaviour of the Norway lobster, Nephrops norvegicus (L.) during trawling. Scottish Fisheries Research Rep., 34: 23.

MarTín, P., 1991. La pesca en Cataluña y Valencia (NO Mediterráneo): análisis de las series históricas de captura y esfuerzo. Inf. tec. de Sci. mar. (CSIC), 162: 43.

RELINI ORSI, L. \& M. WURTZ, 1977. Aspetti delle rete trofica riguardanti Aristeus antennatus (Risso, 1816) (Crustacea, Penaeidae). Atti. IX Congr. Soc. Italiana Biol. mar., Ischia: 389-398.

SARDÀ, F., 1993. Bio-ecological aspects of the decapod crustacean fisheries in the western Mediterranean. Aquat. Liv. Res., 6: 299-305.

SARDÀ, F., C. BAS \& J. LLEONART, 1995. Functional morphometry of Aristeus antennatus Risso, 1816 (Decapoda, Aristeidae). Crustaceana, 68: 461-471.

SARDÀ, F., C. BAS, M. ROLDÁN, C. Pla \& J. LlEONART (in press). Enzymatic and morphometric analyses in Mediterranean populations of rose shrimp Aristeus antennatus (Risso, 1816). Journ. exp. mar. Biol. Ecol.

SARDÀ, F. \& J. E. CARTES, 1993. Relationship between size and depth in decapod crustacean populations on the deep slope in the western Mediterranean. Deep-Sea Res., 40 (11/12): 2389-2400.

— — \& —, 1997. Morphological features and ecological aspects of juvenile specimens of the aristeid shrimp Aristeus antennatus (Risso, 1816). Mar. Freshwater Res., 48: 73-77.

SARDÀ, F., J. E. CARTES \& W. NORBIS, 1994. Spatio-temporal structure of the deep-water shrimp Aristeus antennatus Risso, 1816 (Decapoda: Aristeidae) population in the western Mediterranean. Fish. Bull. NOAA, 92 (3): 599-607.

SARDÁ, F. \& M. DEMESTRE, 1989. Shortening of the rostrum and rostral variability in Aristeus antennatus (Risso, 1816). Journ. Crust. Biol., 9 (4): 570-577.

SOKAL, R. R. \& F. J. ROHLF, 1979. Biometría: 1-832. (H. Blume Ediciones, Madrid).

TOBAR, R. \& F. SARDÀ, 1987. Análisis de la evolución de las capturas de gamba, Aristeus antennatus (Risso, 1816), en las últimos decenios en Cataluña. Informes Técnicos de Investigación Pesquera CSIC, 142: 1-20.

- $-\&$ - - , 1992. Annual and diel light cycle as a predictive factor in the fisheries for the prawn (Aristeus antennatus Risso, 1816). Fish. Res., 15 (1-2): 169-179. 


\title{
TAXONOMIC COMPOSITION AND GRAZING RATE OF CALANOID COPEPODS IN COASTAL WATERS OF NORTHERN TAIWAN
}

\author{
BY \\ J. S. HWANG ${ }^{1}$ ), Q. C. $\mathrm{CHEN}^{2}$ ) and C. K. WONG ${ }^{3,4}$ ) \\ ') Institute of Marine Biology, National Taiwan Ocean University, Keelung 20224, \\ Taiwan, R.O.C. \\ $\left.{ }^{2}\right)$ South China Sea Institute of Oceanology, Academia Sinica, Guangzhou, China \\ ${ }^{3}$ ) Department of Biology, The Chinese University of Hong Kong, Shatin, Hong Kong
}

\begin{abstract}
Taxonomic composition and grazing rate of calanoid copepods in coastal waters in the northern tip of Taiwan was studied in May 1996. During the study period chlorophyll $a$ concentrations in the upper $2 \mathrm{~m}$ of the water column were low. Twenty-five species of calanoid copepods were identified. Acrocalanus gracilis, Canthocalanus pauper, Temora discaudata, Temora turbinata, and Undinula vulgaris were found over the entire study area. Gut pigment content of 17 species was measured with the gut fluorescence method. The variability of the gut pigment contents for a single species among the sampling stations comprised about a factor 2 to 4 . Ingestion rates and clearance rates were calculated from gut pigment data. The highest values were observed in Temora discaudata, Temora turbinata, and Undinula vulgaris.
\end{abstract}

\section{RÉSUMÉ}

La composition taxonomique et le taux d'alimentation des copépodes calanoïdes dans les eaux côtières de la pointe nord de Taiwan ont été étudiés en mai 1996. Pendant la période d'étude les concentrations de chlorophylle $a$ dans les deux mètres supérieurs de la colonne d'eau étaient faibles. Vingt-deux espèces de copépodes ont été identifiées. Acrocalanus gracilis, Canthocalanus pauper, Temora discaudata, Temora turbinata et Undinula vulgaris ont été trouvés sur toute l'aire étudiée. Le contenu en pigment intestinal a été mesuré par la méthode de fluorescence de l'intestin. La variabilité de la teneur en pigment intestinal pour une espèce particulière parmi les stations d'échantillonnage était comprise entre les facteurs 2 et 4 . Les taux d'ingestion et les taux d'évacuation ont été calculés d'après les données sur le pigment intestinal. Les plus hautes valeurs ont été observées chez Temora discaudata, Temora turbinata et Undinula vulgaris.

$\left.{ }^{4}\right)$ Corresponding author. 